\title{
The progestogen challenge test in postmenopausal women: Clinical and morphologic aspects
}

\author{
Discipline of Gynecology, Escola Paulista de Medicina, Universidade Federal de São Paulo - São Paulo, Brazil
}

\begin{abstract}
The clinical aspects and anatomopathological patterns of 150 postmenopausal women were studied using the progestogen challenge test. An endometrial biopsy was obtained and submitted to the progestogen test. A histopathological analysis of the uterine mucosa from women with a positive progestogen test revealed that the endometrium was active in 44 percent of cases and atrophic or inactive in 56 percent. In contrast, among women with a negative response, the endometrium was atrophic in 94 percent of cases and active in 6 percent. Analysis of clinical aspects did not show significant differences between groups in terms of age; age at menarche and at menopause; fasting blood glucose levels; or body mass. However, postmenopausal time was significantly shorter for women with a positive test, with a correlation between postmenopausal time of one to two years and test positivity. The progestogen challenge test for the detection of atrophic endometrium presented 78.57 percent sensitivity, 77.05 percent specificity, 44 percent positive predictive value, and 94 percent negative predictive value. Thus, when negative, the test is highly valuable, indicating the presence of atrophic endometrium in 94 percent of cases. False-negative results occurred in only 6 percent of the subjects, with no case of hyperplasia detected. However, when the response to the test was positive, the endometrium was atrophic in 56 percent of the cases. We suggest that, in order to avoid invasive procedures, the progestogen challenge test be combined with other methods such as transvaginal ultrasonography.
\end{abstract}

UNITERMS: Endometrium. Progesterone. Menopause.

\section{INTRODUCTION}

$\mathrm{A}$ ccording to the International Menopause Society, the climacteric is defined as the transition between the period of greatest reproductive capacity (menacme) and old age. ${ }^{1.2}$ With improved socio-economic conditions worldwide, a related increase in population longevity has occurred. Consequently a greater number of women have reached climacteric. Thus, 90 percent of the North American female population now reaches menopause, with a mean life expectancy of 80 years. The mean age at

\author{
Address for correspondence: \\ Claudia de Carvalho Ramos Bortoletto \\ Rua Henrique Martins, 483 - Jardim Paulista \\ São Paulo/SP - Brasil - CEP 04504-000
}

onset of menopause is 51.4 years, indicating that women will have approximately 30 years of life after menopause. ${ }^{3}$

If the trend is that women will spend approximately 30 percent of their life in a postmenopausal condition, occurrences during this period will directly affect their quality of life. With further developments in the field of medicine, there is the possibility of ensuring a better quality of life for postmenopausal women.

Many studies have been conducted on the auxiliary methods of treatment during menopause, especially in terms of the investigation of the uterine mucosa, an important site of precancerous and carcinomatous lesions. Regressive histological patterns are preponderant during the postmenopausal period as a direct result of the fall in estrogen levels; ${ }^{1.4}$ cancer of the endometrium is considered to be a disease predominent among postmenopausal women, with a frequency of 80 percent during this period..$^{5}$ 
Many procedures have been used to determine the real status of the uterine mucosa in menopausal women. During the last decade, the endometrial biopsy has been recognized as a useful and effective technique. As it is carried out in the laboratory, causing little patient discomfort and offering high diagnostic accuracy, the procedure has permitted a drastic reduction in the number of curettages and has optimized gynecological approaches. ${ }^{6.7}$

The cost of an endometrial biopsy is approximately 10 times less than that of uterine curettage, and the procedure involves a lower surgical risk and provides accuracy ranging from 95 to 98 percent when compared to curettage or other surgical procedures. ${ }^{18} \mathrm{~A}$ biopsy, however, is still an invasive technique.

There are still other non-invasive methods that have been used to study the uterine mucosa. Among them is the progesterone challenge test or the test using synthetic progestogens. In 1980, GAMBRELL et al. utilized and definitely sanctioned the use of the test for menopausal women. They applied the test to 5263 postmenopausal women in order to identify patients at risk for developing hyperplasia and carcinoma of the endometrium. When genital bleeding occurred, they repeated the progestogen test monthly for a varying period of time until the test became negative. Among women not submitted to hormonal treatment, approximately 35 percent experienced bleeding in response to the test. ${ }^{9.10}$

Later, HANNA et al. (1983) administered oily progesterone intramuscularly in $100 \mathrm{mg}$ doses to 30 postmenopausal and asymptomatic women, 10 of whom were using equine-conjugated estrogens. They had previously obtained an endometrial biopsy from each woman from the four quadrants using a Novak curette. Five responded to the test with bleeding; of these patients, three presented endometrial hyperplasia (60 percent) and two atrophic endometrium (40 percent). In the second group of 10 women, known to have a hyperplastic uterine mucosa, they obtained one false-negative result (10 percent). The authors therefore suggested that the progestogen challenge test be added to the medical arsenal for the evaluation of climacteric women. ${ }^{.1}$

ERNY et al. (1986) later performed the progesterone test 1,633 times, with a 12.8 percent rate of positive tests. Among 156 women with a positive test submitted to curettage, the anatomopathological findings revealed an atrophic endometrium in 79 (50.6 percent). In the group with negative tests, one woman had adenocarcinoma of the endometrium..$^{12}$ Other researchers have obtained 71.4 percent test accuracy and recommended the use of the test for all postmenopausal women, and the investigation of endometrial histology for those with a positive response. ${ }^{13}$
In a pioneering study in Brazil, WEHBA (1988) compared the histopathological analysis of the endometrium obtained by curettage from 50 postmenopausal women with a positive or negative result on the progestogen challenge test, in order to study the value of the test in the detection of hyperplastic lesions of the endometrium. The author obtained 12 positive results ( 24 percent) and 38 negative results ( 76 percent). In the positive tests, the endometrium showed proliferative activity in all cases, and was hyperplastic in 50 percent. When the test was negative, the endometrium presented early proliferative activity in only 13.2 percent. In the remaining patients, atrophy was detected in 73.7 percent, or the material was considered inadequate in 13.2 percent. This study made a decisive contribution to the introduction of the progestogen challenge test in Brazil as a routine approach to the monitoring of postmenopausal women. ${ }^{14}$

MACIA et al. (1993) later studied asymptomatic postmenopausal women not submitted to hormonal replacement. According to these researchers, the progestogen challenge test presented 100 percent specificity, as it was negative in all patients with an atrophic endometrium. In addition, sensitivity was 76 percent as among the 89 women with a negative test, and the endometrium was proliferative or hyperplastic in three. ${ }^{15}$

Others authors observed that 26 of 187 asymptomatic postmenopausal women not submitted to hormone therapy did not present atrophy of the uterine mucosa. The test was positive in 16 of these patients ( 61.5 percent), but negative in 10 (38.4 percent). These findings show that false-positive results may be obtained with the progestogen challenge test. ${ }^{16}$

However, few studies are available that compare a positive or negative response to the progestogen challenge test with the respective histopathological findings. Thus, the objectives of the present study were to evaluate women with positive and negative progestogen challenge tests in terms of age; age at menarche and menopause; duration of menopause; body mass index; fasting blood glucose levels and endometrial histopathology; and to calculate the sensitivity and specificity, as well as the positive and negative predictive values of the progestogen challenge test, with respect to the histological type of endometrium.

\section{PATIENTS AND METHOD}

The study was conducted on 150 postmenopausal women seen at the Sector of Endocrine Gynecology and 
Climacteric of the Discipline of Gynecology, Escola Paulista de Medicina, from September 1992 to November 1993. A woman was considered postmenopausal when she was more than 40 years old, with at least one year of amenorrhea and high levels of follicle stimulating hormone (FSH) and luteinizing hormone (LH) ${ }^{1.14}$

The exclusion criteria were as follows: non-spontaneous menopause; postmenopausal genital bleeding; hormonal replacement treatment during the climacteric; liver, heart, kidney and thyroid disease; cancer of the endometrium or of the breast; and conditions that would prevent transvaginal ultrasound examination or anatomopathological study of the endometrium. Each patient was submitted to clinical and hormonal evaluation and to an anatomopathological examination of the endometrium, and the following clinical data was recorded: age, race, marital status, age at menarche and at menopause, duration of menopause, weight, height, and body mass index. Body mass index was calculated by the weight/height ${ }^{2}$ ratio. ${ }^{17}$

Endometrial fragments were obtained with a modified Novak curette. The biopsy always included the anterior, posterior and lateral walls of the uterine cavity. The material destined for histological study by light microscopy was immediately placed in 10 percent formalin and then embedded in paraffin. Blocks were cut with a microtome adjusted to $5 \mu \mathrm{m}$ thickness, and slides were stained with hematoxylin-eosin. The endometrium was then studied morphologically by a single examiner.

The morphologic study was carried out on the entire extension of the histological section using a common binocular Zeiss microscope with a $10 x$ eyepiece and objectives with 4 to $100 \mathrm{x}$ magnification.

The endometrium was classified histologically as:

1. inactive: atrophic endometrium.

2. active: any endometrial pattern other than atrophy, i.e., proliferative, mixed, secretory, with polyps, and typical or atypical hyperplasia.

The progestogen challenge test was performed after the endometrial biopsy. Medroxyprogesterone was administered by the oral route at the dose of $10 \mathrm{mg} /$ day for 10 consecutive days. ${ }^{9.15 .18}$ The test was performed only seven to 10 days after the uterine mucosal biopsy in order to prevent a possible confusion between bleeding occurring naturally after the procedure, and a positive response to the test. The test was considered positive when bleeding occurred, and negative when no bleeding occurred.

On the basis of the progestogen challenge test, we obtained a group of 50 women with a positive result (Group I), and a control group of 100 women with a negative result
(Group II). The women were also classified into four groups according to how long they had been menopausal:

- Group 1, women with a menopause duration of one to two years;

- Group 2, women with a duration of three to five years;

- Group 3, women with a duration of six to 10 years;

- Group 4, women who had been menopausal for 11 or more years.

Data were analyzed statistically by the following nonparametric tests, taking into consideration the nature of the values of the variables studied: Mann-Whitney test, chi-square test ${ }^{19}(\mathrm{p}<0.05)$, test of specificity and sensitivity, and positive and negative predictive value. ${ }^{20}$ The level of significance was set at 5 percent, and significant values are indicated by an asterisk.

\section{RESULTS}

Table 1 lists the data pertaining to the histological pattern of the endometrium of women with a positive and negative test. Among women with a positive progestogen challenge test (Group I), a histopathological analysis of the uterine mucosa revealed an active endometrium in 44 percent of cases, and atrophic or inactive endometrium in 56 percent. In the group with an active endometrium, the endometrium was proliferative in 16 percent of cases, secretory in 10 percent, with typical hyperplasia in 8

Table 1

The histopathological pattern of the endometrium

of women with a positive (Group I) and negative (Group II) progestogen challenge test.

\begin{tabular}{lcccc}
\hline Histopathology & \multicolumn{2}{c}{ Group I } & \multicolumn{2}{c}{ Group I } \\
& N & $\%$ & N & $\%$ \\
\hline Atrophic (inactive) & 28 & 56.0 & 94 & 94.0 \\
Active & & & & \\
Proliferative & 8 & 16.0 & 2 & 2.0 \\
Secretory & 5 & 10.0 & 2 & 2.0 \\
Typical hyperplasia & 4 & 8.0 & - & - \\
Mixed & 2 & 4.0 & 1 & 1.0 \\
Poplyp & 2 & 4.0 & 1 & 1.0 \\
Atypical hyperplasia & 1 & 2.0 & - & - \\
Total & 50 & 100.0 & 100 & 100.0 \\
\hline & & & &
\end{tabular}


Table 2

The means values of age, age at menarche and at menopause, postmenopausal time, body mass index (BMI) and glucose levels $(\mathrm{mg} / \mathrm{dl})$ in women with positive (Group I) and negative (Group II) progestogen challenge test.

\begin{tabular}{lcccccc}
\hline Group & Age & $\begin{array}{c}\text { Age at } \\
\text { Menarche }\end{array}$ & $\begin{array}{c}\text { Age at } \\
\text { Menopause }\end{array}$ & $\begin{array}{c}\text { Postmenopausal } \\
\text { Time (Yr) }\end{array}$ & BMI & $\begin{array}{r}\text { Glucose } \\
\text { Levels }\end{array}$ \\
\hline I & 54 & 13.1 & 48.1 & $5.8^{*}$ & 27.4 & 107.3 \\
II & 55.1 & 13.3 & 47.8 & $7.2^{*}$ & 26.5 & 102.1 \\
\hline
\end{tabular}

Mann-Whitney test (Group I x Group II)

zcritical $=1.96$

\begin{tabular}{lcr}
$\begin{array}{l}\text { Age } \\
\text { zcal }=0.85 \quad \text { zcalc at Menarche }=0.67\end{array}$ & $\begin{array}{c}\text { Age at Menopause } \\
\text { zcalc }=0.61\end{array}$ & $\begin{array}{c}\text { Glucose Levels } \\
\text { zcalc }=0,98\end{array}$ \\
$\begin{array}{l}\text { PostmenopausalTime } \\
\text { zcalc }=2.33^{*}\end{array}$ & BMI & \\
Group I $<$ Group II & zcalc $=1.11$ & \\
\hline
\end{tabular}

of individuals with an active endometrium when the test is positive, was 44 percent. The negative predictive value was 94 percent, i.e., when the test was negative, the endometrium was inactive in 94 percent of the cases.

\section{DISCUSSION}

The endometrium differs from other human tissues mainly by being the target of female sex steroids. Its development and regression cycles are tied to the cyclic estroprogestative oscillations. Thus, it represents a hormone-dependent mucosa that reflects the endocrine activity of human gonads.

percent, with a polyp in 4 percent, mixed in 4 percent, and with atypical hyperplasia in 2 percent.

Among women with a negative response, the endometrium was atrophic in 94 percent of cases and active in 6 percent. Among the latter cases, the endometrium was secretory in 2 percent, proliferative in 2 percent, mixed in 1 percent, and with an endometrial polyp in 1 percent.

Table 2 lists data about women with a positive (Group I) and negative (Group II) test in terms of age, age at menarche and at menopause, postmenopausal time period, body mass index, and fasting blood glucose levels. After analysis by the Mann-Whitney test, only postmenopausal time was significantly shorter in women with a positive test, while the remaining parameters did not differ significantly between groups. Thus, it was demonstrated that menopausal time was significantly shorter in the group of women with a positive progestogen challenge test (a mean of 5.8 years for Group I and of 7.2 years for Group II).

Table 3 shows the relationship between postmenopausal time and response to the test. It was concluded that there was a significant association between a menopausal time of 1 to 2 years and a positive test.

The sensitivity, specificity, and positive and negative predictive values of the test are listed in Table 4. Sensitivity, defined as the ability of the test to detect individuals with a non-atrophic endometrium, was 78.57 percent. Specificity, i.e., the ability of the test to select normal women with an atrophic endometrium, was 77.05 percent. The positive predictive value, defined as the percentage
Our histopathological findings, listed in Tables 1 and 2 , demonstrate that an inactive endometrium was detected in 94 percent of the women with a negative progestogen challenge test, and in 56 percent of women with a positive test. To determine the value of the test by discriminating between populations, especially with respect to eventual risk factors for neoplasias of the endometrium, we compared some variables between Groups I (negative test) and II (positive test), listed in Table 2. We deduced that there were no significant differences between women with a positive or negative test in terms of age, age at menarche, age at menopause, body mass index, or fasting blood glucose levels.

In our study, the mean age of women with a positive progestogen challenge test was 54 years, and the mean age of women with a negative test was 55.1 years. Analysis of the literature did not reveal significant differences between the two groups in terms of age. ${ }^{13.14 .21}$ We also

Table 3

Postmenopausal time in Group I and II.

\begin{tabular}{lccccc}
\hline Postmenopausal & \multicolumn{2}{c}{ Group I } & \multicolumn{2}{c}{ Group II } & Total \\
time (years) & $N$ & $\%$ & $N$ & $\%$ & \\
\hline $1-2$ & 25 & 50.0 & 24 & 24.0 & 49 \\
$3-5$ & 8 & 16.0 & 31 & 31.0 & 39 \\
$6-10$ & 8 & 16.0 & 23 & 23.0 & 31 \\
$11+$ & 9 & 18.0 & 22 & 22.0 & 31 \\
\hline
\end{tabular}


found no differences in terms of age at menarche or age at menopause. WEHBA (1988) detected a significantly lower age at menarche among patients with a positive test, but did not observe the same phenomenon with respect to age at menopause. ${ }^{14}$

Another risk factor for carcinoma of the endometrium considered in the present study was diabetes mellitus. A quite controversial factor, diabetes mellitus has been considered to result from other variables, especially obesity. ${ }^{22,23}$ Indeed, obesity leads to increased estrogen levels in postmenopausal women and consequently represents an important risk factor for endometrial carcinoma. ${ }^{24}$

HEMPEL et al. (1988) also applied the progestogen challenge test to groups of diabetic and non-diabetic menopausal women. Despite mentioning diabetes mellitus as a risk factor for cancer of the endometrium, the authors did not report a significantly higher number of positive tests in the diabetic group. ${ }^{24}$ Similarly, WEHBA (1988) did not detect an association of positivity with fasting blood glucose levels. ${ }^{14}$

The literature has not observed differences in body mass index between women with positive and negative tests. ${ }^{14.21}$ Our study also showed no significant differences in fasting blood glucose levels and body mass index between the groups with positive and negative tests (Table 2).

On the other hand, postmenopausal time was significantly longer in women with a negative test (mean, 7.2 years) compared to women with a positive test (mean, 5.8 years). We further divided the women according to menopausal time and submitted their data to statistical analysis (Table 3). The group of women with menopausal time of one to two years presented a significant association with a positive progestogen challenge test. These findings can be explained by remembering that circulating estrogen levels are increased during perimenopause, with a slow decline occurring over subsequent years. ${ }^{25}$ Furthermore, metabolic clearance and production of estrone and estradiol decrease with passing time.

Thus, the proliferative and hyperplastic histological patterns occurring during the postmenopausal period are usually observed during the first years after the onset of menopause, with the incidence of uterine mucosal atrophy increasing with postmenopausal time. ${ }^{16}$ Thus, a greater positivity of the test is to be expected during the first years after menopause. VALENZUELA et al. (1993) concluded that women with a postmenopausal time of five years or more present a lower risk of positivity to the test. ${ }^{21}$

Few authors have related the progestogen challenge test to the histological investigation of the endometrium,

\begin{tabular}{|c|c|c|c|}
\hline \multicolumn{4}{|c|}{$\begin{array}{c}\text { Table } 4 \\
\text { The sensitivity, specificity, positive and negative } \\
\text { predictive value of progestogen challenge } \\
\text { test in postmenopause. }\end{array}$} \\
\hline \multirow[t]{2}{*}{ Progestogen test } & \multicolumn{2}{|c|}{ Endometrium } & \multirow[t]{2}{*}{ Total } \\
\hline & Active & Inactive & \\
\hline Positive & 22 & 28 & 50 \\
\hline Negative & 6 & 94 & 100 \\
\hline Total & 28 & 122 & 150 \\
\hline
\end{tabular}

Sensitivity $=78.57 \%$

Specificity $=77.05 \%$

Positive predictive value $=44 \%$

Negative predictive value $=94 \%$

regardless of the result. When the response to the test is positive, atrophic states of the uterine mucosa are detected. Thus, an anatomopathological study of the endometrium of women with a positive test revealed atrophy in 36.9 to 50.6 percent. $^{13.18 .26-28}$

Our results showed endometrial atrophy in 56 percent of the women with a positive test, in agreement with recorded values. This bleeding of the atrophic endometrium during the postmenopausal period may be due to sclerotic degeneration of the endometrial veins, or to local or systemic hypertension, especially in women with senile arteriosclerosis and endometritis. ${ }^{26}$ Also, it is possible that bleeding after the use of progestogen is due to minute foci of active endometrium interspersed throughout an almost completely atrophied mucosa. ${ }^{27}$ However, a negative test usually reflects endometrial inactivity. An active endometrium is detected in 3.4 to 10 percent of the women with a negative test. ${ }^{11.15 .27 .29}$

In our series, we obtained a 6 percent rate of false-negative results, i.e., six cases of active endometrium in women with a negative progestogen challenge test (Table 2). No hyperplasia was observed among women with a negative progestogen challenge test. Thus, we may conclude that the progestogen challenge test is of paramount importance when its result is negative, with a negative predictive value of 94 percent. However, when the response to the test is positive, regressive states of the uterine mucosa are detected, as emphasized by several investigators. ${ }^{18.21 .27 .29}$

These data show that the sensitivity of the progestogen challenge test in detecting endometrial alterations was 78.57 percent and its specificity (the ability to identify women with an atrophic endometrium) was 77.05 percent. The positive predictive value of the test was calculated at 44 
percent, indicating that, when the test is positive, endometrial activity is present in 44 percent of cases.

On this basis, in the evaluation of the uterine mucosa during the postmenopausal period, we believe that the progestogen challenge test, when negative, is reassuring to the physician. However, when the test is positive, other methods, such as transvaginal ultrasonography should be associated with it. In this way, curettage can be avoided from the start, because in more than 50 percent of cases in which the test is positive, the endometrium is atrophic. Therefore, we believe that the progestogen challenge test and transvaginal ultrasonography, performed on postmenopausal women, can determine those requiring other exams, such as hysteroscopy or curettage.

\section{ReSUMO}

Estudaram-se os aspectos clínicos e o padräo anatomopatológico de 150 mulheres na pós-menopausa, consoante o teste provocativo pelo progestogênio. Realizou-se biópsia de endométrio, seguida pelo teste do progestogênio. Observou-se que, entre as mulheres com teste do progestogênio positivo, a análise histopatológica da mucosa uterina revelou 44 percent de endométrio ativo e 56 percent de atrófico ou inativo. Já as mulheres com resposta negativa, apresentaram 94 percent de endométrio atrófico e 6 percent com endométrio ativo. Analisando-se os aspectos clínicos, nāo se observaram diferenças significantes entre os grupos em relação a idade, idade da menarca e da menopausa, glicemia de jejum e indice de massa corpórea. Entretanto, o tempo de pós-menopausa foi significantemente menor nas mulheres com teste positivo, observandose associação entre tempo de menopausa entre um e dois anos e positividade do teste. O teste provocativo pelo progestogênio para detecçāo de endométrio atrófico apresentou: sensibilidade de 78,57 percent; especificidade de 77.05 percent; valor preditivo positivo de 44 percent e negativo de 94 percent. Portanto, quando negativo, o teste do progestogênio é de grande valia, indicando em 94 percent das vezes endométrio atrófico. Os resultados falso-negativos ocorreram em apenas 6 percent, não se encontrando nenhum caso de hiperplasia. Entretanto, quando a resposta do teste foi positiva, em 56 percent o endométrio foi atrófico. Sugere-se, que no intuito de se evitar a realização de procedimentos invasivos, promova-se a associação do teste do progestogênio com outros métodos propedêuticos, como, por exemplo, a ultra-sonografia transvaginal.

\section{REFERENCES}

1. Baracat EC. Aspectos morfológicos e morfométricos do endométrio humano na pós-menopausa antes e após estrogenioterapia oral e transdérmica. São Paulo, 1991. (Concurso Docente-Livre - Escola Paulista de Medicina).

2. Utian WH. Overview on menopause. Am J Obstet Gynecol 1987; 156:1280-3.

3. American College of Obstetricians and Gynecologists. Carcinoma of Endometrium. Int J Gynecol Obstet 1993;40:255-61.

4. More JAR. The normal human endometrium. In: Fox H, ed. Haines and Taylor Obstetrical and Gynaecological Pathology, 3rd.ed. Edinburg: Churchill Livingstone, 1987:302-19.

5. American College of Obstetricians and Gynecologists. Hormone replacement therapy. Int J Gynecol. Obstet 1993;41:194-202.

6. Fothergill DJ, Brown VA, Hill AS. Histological sampling of the endometrium: a comparison between formal curettage and the Pipelle sampler. Br J Obstet Gynaecol 1992;99:77980.

7. Grönroos M, Salmi TA, Vuento MH, et al. Mass screening for endometrial cancer directed in risk groups of patients with diabetes and patients with hypertension. Cancer 1993;71:1279-82.

8. Lutz MH, Underwood PB, Kreutner A, Mitchell KS. Vacuum aspirator: an efficient outpatient screening technique for endometrial disease. South Med J 1977;70:393-5.

9. Gambrell Jr RD, Massey FM, Castaneda TA, Ugenas AJ, Ricci CA, Wright JM. Use of the progestogen challenge test to reduce the risk of endometrial cancer. Obstet Gynecol 1980;55:732-8.

10. Gambrell JR RD. Progestogen challenge test. Obstet Gynecol 1981;57:268.

11. Hanna JH, Brady WK, Hill JM, Phillips GL. Detection of postmenopausal women at risk for endometrial carcinoma by a progesterone challenge test. Am J Obstet Gynecol 1983;147:872-5.

12. Erny R, Isnard S, Boubli L. Tests aux progestatifs après la ménopause. Rev Fr Gynécol Obstét 1986;81:195-8. 
13. Toppozada MK, Ismail AAA, Hamed RSM, Sid-Ahmed $\mathrm{K}$, El-Faras A. Progesterone challenge test and estrogen assays in menopausal women with endometrial adenomatous hyperplasia. Int J Gynecol Obstet 1988;26:115-9.

14. Wehba S. Teste da progesterona para detecção de lesões hiperplásicas do endométrio em mulheres na pósmenopausa. São Paulo, 1988. (Dissertation, Escola Paulista de Medicina).29. Bortoletto CCR, Gonçalves WJ, Baracat EC, Lima, GR. The use of progestogen challenge test, transvaginal ultrasonography and endometrium biopsy in postmenopause. Int J Gynecol Obstet 1994;46(1):76.

15. Macía M, Novo A, Ces J, Gonzáles M, Quintana S, Codesido J. Progesterone challenge test for the assessment of endometrial pathology in asymptomatic menopausal women. Int J Gynecol Obstet 1993;40:145-9.

16. Gonçalves WJ, Simões RD, Stávale JN, Baracat EC. Estudo histológico do endométrio em mulheres na pós-menopausa. In: Jornada Paulista De Obstetrícia E Ginecologia, 2, Guarujá, São Paulo, 1993:42.

17. Keys A, Fidanza F, Karvonen MJ, Kimura N, Taylor HL. Indices of relative weight and obesity. J Chron Dis 1972;25:329-43.

18. Pansini F, De Paoli D, Serra MM, Campobasso C, Levato F, Giulini D. Combined use of progesterone challenge test and endometrium thickness evaluated by transvaginal ultrasonography in the preventive management of postmenopausal women. Gynecol Obstet Invest 1992;34:237-9.

19. Siegel S. Estadistica no paramétrica. México: Trillas, 1975:346.
20. Gallen RS, Gambino R. Beyond normality: the predictive value and efficiency of medical diagnoses. New York: John Wiley \& Sons, 1975.

21. Valenzuela P, Sabatel RM, Valls V, Nieto A, GonzalezGomez F. Progestin challenge test in postmenopausal patients. Int J Gynecol Obstet 1993;43:313-6.

22. Kneale BLG, Giles GG. Endometrial cancer: trends in incidence and survival: a preventable disease? Aust NZ J Obstet Gynaecol 1993;33:1-7.

23. Parazzini F, La Vecchia C, Bocciolone L, Franceschi S. The epidemiology of endometrial cancer. Gynecol Oncol 1991;41:1-16.

24. Levi F, La Vechchia C, Negri E, Parazzini F, Franceschi S. Body mass at different ages and subsequent endometrial cancer risk. Int J Cancer 1992;50:67-71.

26. Dallenbach-Hellweg $G$. The endometrium in the climateric and after menopause. In: Dallenbach-Hellweg G - Histopathology of the endometrium, 4th ed. New York: Springer-Verlag, 1987:86-92.

25. Shermann BM, West JH, Korenman SG. Analysis of LH, FSH, estradiol and progesterone concentrations during menstrual cycles of older women. J Clin Endocr Metabol 1976;42:629-36.

27. Erny R, Serradimigni F. Dépistage des hyperplasies et des cancers de l'endomètre. Rev Fr. Gynécol Obstét 1984;79:91-6.

28. Hempel VE, Nöschel H, Eichhorn KH, Rasch A, Franke D. Vergleich von progesterntest and uterussonographie als screening-verfahren zur erkennung von risikopatientinnen hinsichtlich endometriumkarzinom. Zentralblatt Gynäkol. 1988;110:597-602. 